BHI-00993

Rev. 0

\title{
Site-Specific Waste Management Instruction - Radiological Screening Facility
}

Author

G. G. Hopkins

Date Published

March 1997

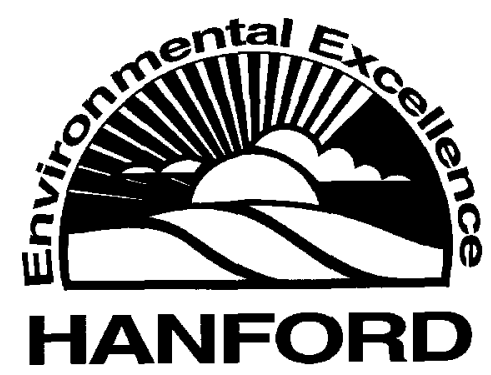

Prepared for the U.S. Department of Energy Office of Environmental Restoration

Bechtel Hanford, Inc.

Richland, Washington 


\section{CONTENTS}

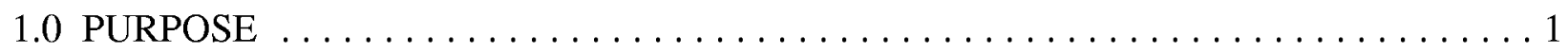

2.0 PROJECTED WASTE STREAMS $\ldots \ldots \ldots \ldots \ldots \ldots \ldots \ldots \ldots \ldots \ldots \ldots$

3.0 WASTE SEPARATION AND SEGREGATION $\ldots \ldots \ldots \ldots \ldots \ldots \ldots \ldots \ldots$

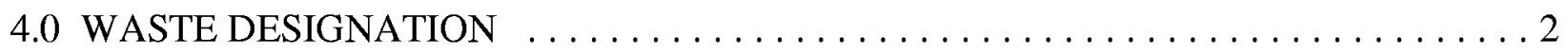

5.0 WASTE PACKAGING AND TRANSPORTATION $\ldots \ldots \ldots \ldots \ldots \ldots \ldots \ldots$

6.0 MARKING AND LABELING $\ldots \ldots \ldots \ldots \ldots \ldots \ldots \ldots \ldots \ldots \ldots \ldots \ldots$

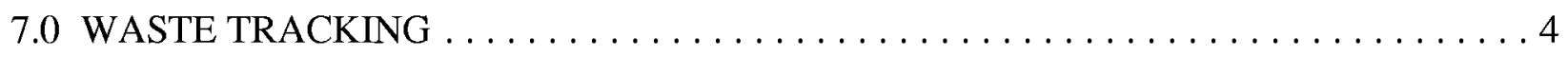

8.0 WASTE INSPECTIONS $\ldots \ldots \ldots \ldots \ldots \ldots \ldots \ldots \ldots \ldots \ldots \ldots \ldots \ldots \ldots$

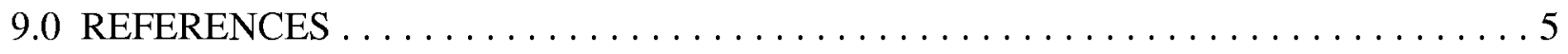


BHI-00993

Rev. 0 
BHI-00993

Rev. 0

\subsection{PURPOSE}

This Site-Specific Waste Management Instruction (SSWMI) provides guidance for managing waste generated from radiological sample screening operations conducted to support the Environmental Restoration Contractor's activities. The following SSWMI is prepared in accordance with BHI-FS-03, Field Support Waste Management Instructions, Procedure $\mathrm{W}-006$, and applies only to waste generated within the radiological screening facilities.

\subsection{PROJECTED WASTE STREAMS}

A variety of materials and environmental samples may be submitted to the radiological screening facility for radiological assessment. The project submitting the sample to the radiological screening facility is responsible for retrieving and managing the sample when screening has been completed. The radiological screening facility will not function as a storage facility or an archive for processed project samples. For ongoing projects that frequently submit samples to the radiological screening facility, the courier delivering the sample should make the return trip with the processed samples. Under no circumstances should processed samples remain at the radiological screening facility in excess of one week.

The only regulated waste generated from within the radiological screening facility should be items such as the following:

- Laboratory ware

- $\quad$ Personal protective equipment (PPE)

- $\quad$ Sanitary wipes

- Other miscellaneous waste laboratory items contaminated during the screening process

- $\quad$ Spent solutions (used in sample preparations such as digestion).

The majority of waste generated in the radiological screening facility will be classified as lowlevel radioactive waste (LLW). The potential exists for hazardous/dangerous or low level radioactive mixed waste (mixed) solutions to be created due to the diagnostic chemistry of any particular solution. Solution $\mathrm{pH}$ will be adjusted to greater than 2.0 but less than 12.5 prior to placing the solution into a waste container. The $\mathrm{pH}$ adjustment will not be made using a chemical that, upon its' addition, render the solution hazardous/dangerous.

Other scenarios that may cause the generation of a hazardous/dangerous or mixed waste include: 
BHI-00993

Rev. 0

- $\quad$ Processing a sample containing a Resource Conservation and Recovery Act of 1976 (RCRA) listed waste

- Solution preparation of samples containing elevated levels or hazardous/dangerous constituents.

These scenarios should be avoided if other options exist.

\subsection{WASTE SEPARATION AND SEGREGATION}

Wastes will be segregated to minimize the potential for cross-contamination and to accommodate waste characterization requirements. Waste will be segregated into the categories of (1) hazardous/dangerous, (2) LLW, (3) and mixed. Further segregation (subcategories) within those three categories would include liquid versus solid or characterized versus uncharacterized waste.

A survey for free release of any items that are potentially radiologically contaminated (laboratory ware, PPE, wipes, etc.) will be conducted whenever feasible. Radioactive waste for which characterization is available will not be mixed with waste for which radionuclidespecific characterization has not been documented.

\subsection{WASTE DESIGNATION}

Wastes will be designated through the application of process knowledge or sample analyses. In most cases, the project can identify an existing waste profile or provide analytical data associated with the site from which the sample was generated to facilitate the waste designation. In cases where the specific chemical or radiological constituents are unknown, funding must be identified to conduct sufficient sample analyses and accurately characterize waste associated with an uncharacterized sample.

The designation will normally be completed and issued by BHI Field Support Waste Management (FSWM) or contract delegate.

\subsection{WASTE PACKAGING AND TRANSPORTATION}

Specific waste packaging is driven by the waste acceptance criteria of the selected disposal site. The waste destined for the Environmental Restoration Disposal Facility (ERDF) will be packaged in accordance with BHI-00139, Environmental Restoration and Disposal Facility Waste Acceptance Criteria (BHI 1996). Waste destined for offsite disposal facilities, 
BHI-00993

Rev. 0

200 West Area Central Waste Complex, or 200 Area LLW burial grounds will be packaged in accordance with WHC-EP-0063, Hanford Site Solid Waste Acceptance Criteria.

- $\quad$ Solid LLW may be disposed of at the ERDF or at the 200 Area LLW burial grounds.

- $\quad$ Mixed waste meeting land disposal restriction (LDR) treatment standards may be disposed of at ERDF or at the 200 Area LLW burial grounds.

- $\quad$ Mixed waste that does not meet LDR treatment standards is destined for the 200 West Area Central Waste Complex.

- Hazardous waste will be disposed at an offsite facility.

Containers used to accumulate or transport laboratory waste will be assigned unique container identification numbers. The generator (radiological screening facility personnel) will request the container numbers from FSWM. Unique container identification numbers will be written on the top and side of the container prior to placing waste in the container.

Miscellaneous LLW (e.g., laboratory ware, PPE, wipes, etc.) will be bagged, inventoried, and placed in accumulation containers on a daily basis. Detailed inventory sheets will be maintained for each accumulation container and will include identification of the project that the specific bag of waste is associated with. The ERC Waste Inventory Sheet, (BHI-FS-038) provides the level of detail needed to maintain accumulation container inventory control. As previously indicated, miscellaneous items contaminated by samples from uncharacterized sites will be placed in an accumulation container other than the container accumulating the characterized waste. The LLW accumulation containers may consist of any strong, tight, weather-resistant type of container (not cardboard or fiber board). These containers will be stored in a radioactive materials area (RMA) in compliance with the requirements of the Hanford Site Radiological Controls Manual (HSCRM-1).

All waste containing or suspected of containing regulated levels of hazardous/dangerous waste constituents will be managed in an established satellite accumulation area.

Miscellaneous waste items that are absorptive by nature (e.g., sanitary wipes, PPE, etc.) and that were in intimate contact with spent solutions that may contain regulated levels of hazardous components, or RCRA-listed wastes should be bagged, inventoried, and placed in a UN1A2 painted steel container specifically used for the waste type. Waste that also contains a radioactive component must be contained in a UN1A2 galvanized drum to meet the requirements for mixed waste storage at the 200 West Area Central Waste Complex.

Spent solutions generated from similar processes (e.g., soil digestion preparation) may be accumulated in the same container(s) and a single composite sample may be used to determine waste designation. The size of the container will be function of the estimated volume generated over a period of time. However, for radiological screening facility activities, utilizing the smaller 5-gallon containers provides more flexibility than the larger, more cumbersome 30-or 55-gallon drums. Should the liquid designate as a mixed waste, the 5- 
BHI-00993

Rev. 0

gallon containers may be laboratory-packed in 55-gallon galvanized drums as required to meet the mixed waste acceptance criteria detailed in WHC-EP-0063.

FSWM will provide guidance for final waste packaging, transportation, and disposal pending results of the waste designation.

\subsection{MARKING AND LABELING}

Containers of radioactive waste will be identified with radioactive material labels per the requirements of HSRCM-1.

Hazardous/dangerous waste containers must either have a U.S. Environmental Protection Agengy (EPA) hazardous waste sticker attached, or the words "HAZARDOUS WASTE" applied to the side of the container. In addition, the major risk (i.e., ignitable, corrosive, reactive, toxic) must be displayed in association with the identifiers used (e.g. "HAZARDOUS WASTE -TOXIC"). When the accumulation limit for a particular waste stream is reached (55-gallon hazardous/dangerous or 1 quart acutely hazardous), the container will be sealed, an accumulation start date (seal date) written on the EPA hazardous waste sticker or in association with the optional identifier, "HAZARDOUS WASTE."

Depending upon the final destination of the waste, additional container marking or labeling may be required. The FSWM certified waste shipper will ensure that additional markings are applied as appropriate.

\subsection{WASTE TRACKING}

The Waste Certification Form (WCF) is the document used to initiate the waste tracking process. The WCF facilitates and documents the request and issuance of a waste container and a unique container identification number. The WCF is also used to document review and verification of appropriate waste packagings. A copy of the WCF is used by FSWM to input container information into the Solid Waste Information Tracking System (SWITS).

\subsection{WASTE INSPECTIONS}

The satellite accumulation area (i.e., the storage area established to manage accumulating hazardous/dangerous wastes) will be inspected weekly by the radiological screening facility personnel. FSWM will inspect the satellite area on a monthly basis and document the inspection on an Inspection Log (Jet Form BC-5400-321). If the satellite area includes a 
RMA, FSWM will document the monthly inspection on Form BHI-FS-115, Field Support Waste Management Radioactive Material Area Inspection.

All RMAs, whether or not they contain hazardous/dangerous waste, require monthly documented inspections by the cognizant custodian.

\subsection{REFERENCES}

BHI, 1996, Environmental Restoration Disposal Facility Waste Acceptance Criteria, BHI-00139, Rev. 2, Bechtel Hanford, Inc., Richland, Washington.

BHI-FS-03, Field Support Waste Management Instructions, Bechtel Hanford, Inc., Richland, Washington.

HSCRM-1, Hanford Site Radiological Control Manual, Hanford Site Contractors, Richland, Washington.

Resource Conservation and Recovery Act of 1976, 42 U.S.C. 9601 et seq., as amended.

WHC, 1993, Hanford Site Solid Waste Acceptance Criteria, WHC-EP-0063-4, Westinghouse Hanford Company, Richland, Washington. 